\title{
Evaluation of physicochemical and antioxidant properties of two stingless bee honeys: a comparison with Apis mellifera honey from Nsukka, Nigeria
}

\author{
Justus Amuche Nweze, J. I. Okafor, Emeka I. Nweze ${ }^{*}$ and Julius Eyiuche Nweze
}

\begin{abstract}
Objective: Several physical, biochemical and antioxidant properties of two Nigerian stingless bee honey varieties (Melipona sp. and Hypotrigona sp.) were compared with Apis mellifera honey using standard analytical procedures.

Results: The mean pH of Apis mellifera, Hypotrigona sp. and Melipona sp. honeys were 4.24 $\pm 0.28,3.75 \pm 0.11$ and $4.21 \pm 0.37$ respectively. The mean moisture contents of the honeys were $11.74 \pm 0.47,17.50 \pm 0.80$, and $13.86 \pm 1.06 \%$. Honey samples from Hypotrigona sp. when compared with other honey samples had the highest mean total dissolved solids (370.01 $\pm 22.51 \mathrm{ppm})$, hydroxymethylfurfural (16.58 $\pm 0.37 \mathrm{mg} / \mathrm{kg})$, total acidity $(35.57 \pm 0.42 \mathrm{meq} / \mathrm{kg})$, protein content $(16.58 \pm 0.37 \mathrm{~g} / \mathrm{kg})$, phenol content $(527.41 \pm 3.60 \mathrm{mg} / \mathrm{kg})$, and ascorbic acid $(161.69 \pm 6.70 \mathrm{mg} / \mathrm{kg})$, antioxidant equivalent—ascorbic acid assay value (342.33 $\pm 0.78 \mathrm{mg} / \mathrm{kg})$ as well as ferric reducing power $(666.88 \pm 1.73 \mu \mathrm{M}$ Fe(II)/100 g) $(p<0.05)$. Several strong correlations were observed among some of the parameters of the honeys. This is the first study to compare the properties of Nigerian honey bees. Our results suggested that these honeys (specifically Hypotrigona sp. honey) is a good source of antioxidants comparable to $A$. mellifera honey.
\end{abstract}

Keywords: Stingless, Honey, Physicochemical, Antioxidants, HMF, Phenolics, Flavonoids, Ascorbic acid, FRAP, AEAC

\section{Introduction}

Honey is a natural sweet sticky and viscous solution produced by honey insects from the nectar of flowers or from living parts of plants. The nectar is transformed into honey by honey bees and stored in the pot-like comb or waxy honeycomb inside the hive to ripen and mature for further use. Honey is a mixture of substances composed of mainly sugars and water, as well other compounds (less than $1 \%$ ) such as proteins, minerals, enzymes, vitamins, 5-hydroxymethylfurfural (HMF), volatile compounds, flavonoids, and phenolic acids [1].

Even though honey is produced worldwide, its composition and antimicrobial activity can be variable, and are dependent primarily on their botanical origin,

*Correspondence: emeka.nweze@unn.edu.ng

Department of Microbiology, Faculty of Biological Sciences, University of Nigeria, Nsukka 41001, Nigeria geographical and entomological source [2]. Other certain external factors, such as harvesting season, environmental factors, processing and storage condition, also play important roles [3]. Honey contains significant antioxidant compounds including ascorbic acid, flavonoids, glucose oxidase, amino acids, proteins phenolic acids, organic acids, carotenoid derivatives, and maillard reaction products $[1,3]$. The biological properties that make it ideal as a medicine are: antibacterial, bacteriostatic, anti-inflammatory, wound and sunburn healing effects, antioxidant activity, radical scavenging activity and antimicrobial activity [3, 4].

Previous studies have reported some of the physicochemical properties of Nigerian honey from Apis mellifera [5-9] and stingless bee [10] but to our knowledge there is scanty or no report on antioxidant properties of honeys from stingless bees usually found in Nsukka, 
Nigeria. Therefore, the aim of this study was to evaluate and compare the physico-chemical and antioxidant properties of three varieties of honeys from A. mellifera, Hypotrigona sp. and Melipona sp.

\section{Main text \\ Materials and methods Collection of honey samples}

Nine multi-floral honey samples, two each from Apis mellifera, Hypotrigona sp. (locally called Okotobo in Igbo, Nsukka, Nigeria) and Melipona sp. (Ifufu or Ihuhu) were collected from different bee-keepers at Igbo Eze North Local Government Area (Enugu Ezike), in Enugu State (Nigeria) between June and July, 2015. The honey samples were harvested and kept at $5{ }^{\circ} \mathrm{C}$.

\section{Physicochemical analyses}

The $\mathrm{pH}$ of a $10 \%(\mathrm{w} / \mathrm{v})$ solution was measured according to Association of Official Analytical Chemists methods [11]. The moisture content was determined based on the refractometric method of International Honey Commission [2]. A $20 \%(w / v)$ solution of honey was prepared and using conductivity meter, electrical conductivity (EC) and total dissolved solids (TDS) of each sample were measured [12]. The colours of the honey samples were determined by spectrophotometric method according to the method of White [13] and the colour intensities $\left(\mathrm{ABS}_{450}\right)$ were determined using the method of Beretta et al. [14].

\section{Biochemical analyses}

The refractometric technique was used to determine the total sugar contents (TSC) of a $25 \%(\mathrm{w} / \mathrm{v})$ solution of honey [15] and using glucose standard solutions (100$600 \mu \mathrm{g} / \mathrm{mL}$ ), the reducing sugar content was measured according to Saxena et al. [16] and the amount of sucrose content (\%) was measured [15]. A technique based on the method described by Winkler was used to determine the HMF content of the samples [17] and it was calculated $(\mathrm{mg} / \mathrm{kg})$ according to Auerbach and Borries [18]. Using Lowry's method [19], the protein content of honey was determined while the free acidities and lactones contents were determined by equivalence point titration according to IHC [2].

\section{Analysis of antioxidant potentials}

By using spectrophotometric Folin-Ciocalteu method [20], total phenolic content was determined based on gallic acid standard solutions $(20-100 \mu \mathrm{g} / \mathrm{mL} ; \mathrm{y}=0.0017 \mathrm{x}-$ $0.0104)$. The colorimetric assay used by Zhishen et al. was used to measure the flavonoid content [21] using a standard solution of catechin $(20-100 \mu \mathrm{g} / \mathrm{mL} ; \mathrm{y}=0.0136 \mathrm{x}$ $-0.0092)$. A method established by the IHC was used to estimate proline content [2] and the ascorbic acid content was determined based on the method described by Ferreira et al. [22], using a standard solution of pure $\mathrm{L}$-ascorbic acid (50-400 $\mu \mathrm{g} / \mathrm{mL} ; \mathrm{y}=3.2460 \mathrm{x}-0.0614)$. The antioxidant content was determined by measuring antioxidant equivalent ascorbic acid content (AEAC) values using the method described by Meda et al. [23] and a standard solution of pure L-ascorbic acid $(1-8 \mu \mathrm{g} / \mathrm{mL}$; $y=0.2746 x-0.0943)$. The ferric reducing/antioxidant power (FRAP) assay ( $\mu$ MFe(II)) was determined using the procedure described by Bertoncelj et al. [24].

\section{Statistical analyses}

Results were reported as the mean \pm standard deviation of duplicate experiments. Using SPSS statistical package (version 23), ANOVA and post hoc multi-comparison test were used for comparison of means $(p<0.05)$. Several parameters were correlated using Pearson's correlation coefficient $(\mathrm{r})(p<0.01)$.

\section{Results}

All the honey samples tested were acidic and the $\mathrm{pH}$ values of the honey samples varied (Table 1). There were significant differences between the mean values of $\mathrm{pH}\left(\mathrm{F}_{(2,24)}=30.99\right)$, TDS $\left(\mathrm{F}_{(2,24)}=154.591\right)$, EC $\left(\mathrm{F}_{(2,24)}=20.908\right)$, TDS $\left(\mathrm{F}_{(2,24)}=154.591\right)$ and $\mathrm{ABS}_{450}$ $\left(\mathrm{F}_{(2,15)}=169.73\right)(p<0.05)$ of the honey varieties. Hypotrigona sp. honey had significantly the lowest mean $\mathrm{pH}$ value $(3.75 \pm 0.105, p<0.05)$. A significantly highest mean values of moisture contents $(17.50 \pm 0.80 \%)$, EC $(0.303 \pm 0.04 \mathrm{mS} / \mathrm{cm})$, and TDS $(370.01 \pm 22.51 \mathrm{ppm})$ were found in Hypotrigona sp. honey $(p<0.05)$ (Table 1$)$. $A$. mellifera and the other two honey varieties were amber and light amber in colour (Pfund scale table), respectively.

There were statistically significant differences between the mean content values of total sugar $\left(\mathrm{F}_{(2,24)}=53.765\right)$, reducing sugar $\left(\mathrm{F}_{(2,24)}=35.303\right)$, sucrose $\left(\mathrm{F}_{(2,24)}=140.198\right),\left(\mathrm{F}_{(2,24)}=250.031\right)$, Total $\left(\mathrm{F}_{(2,24)}=6492.145\right)$, free $\left(\mathrm{F}_{(2,24)}=3524.638\right)$ and lactone $\left(\mathrm{F}_{(2,24)}=123.790\right)$ acidities of the honey varieties (Table 2). The honey from Melipona sp. had significantly the highest mean values of total sugars $(80.71 \pm 1.37 / 100 \mathrm{~g})$, reducing sugars $(75.64 \pm 1.99 / 100 \mathrm{~g})$ and sucrose $(5.06 \pm 0.75 \%)$ contents while the Hypotrigona sp. honey had significantly the highest mean values of HMF $(16.58 \pm 0.37 \mathrm{mg} / \mathrm{kg})$, protein content $(16.58 \pm 0.37 \mathrm{~g} /$ $\mathrm{kg})$, total $(35.57 \pm 0.42 \mathrm{meq} / \mathrm{kg})$, free $(30.69 \pm 0.32 \mathrm{meq} /$ $\mathrm{kg})$ and lactone $(4.88 \pm 0.61 \mathrm{meq} / \mathrm{kg})$ acidities $(p<0.05)$ (Table 2).

A statistically significant differences were observed between the mean values of polyphenol contents $\left(\mathrm{F}_{(2,24)}=154.982\right)$, flavonoid contents $\left(\mathrm{F}_{(2,15)}=38.25\right)$, proline content $\left(\mathrm{F}_{(2,24)}=14.039\right)$, ascorbic acid 
Table 1 Physico-chemical parameters (pH, moisture, EC, TDS, colour and colour intensity) of various honey varieties

\begin{tabular}{|c|c|c|c|c|c|c|c|}
\hline \multirow[t]{2}{*}{ Honey source } & \multirow[t]{2}{*}{ Samples } & \multicolumn{6}{|l|}{ Parameters } \\
\hline & & $\mathrm{pH}$ & Moisture (\%) & $\mathrm{EC}(\mathrm{mS} / \mathrm{cm})$ & TDS (ppm) & Colour (nm) & $\mathrm{ABS}_{450}(\mathrm{mAU}, 50 \mathrm{w} / \mathrm{v})$ \\
\hline \multirow[t]{3}{*}{ Apis mellifera } & । & $4.46 \pm 0.095$ & $11.870 \pm 0.703$ & $0.163 \pm 0.0153$ & $264.1 \pm 0.59$ & $1.986 \pm 0.001$ & $961.33 \pm 0.58$ \\
\hline & $\|$ & $4.22 \pm 0.077$ & $11.537 \pm 0.454$ & $0.217 \pm 0.1155$ & $282.0 \pm 0.25$ & $2.102 \pm 0.001$ & $988.33 \pm 1.15$ \\
\hline & III & $4.04 \pm 0.124$ & $11.817 \pm 0.301$ & $0.240 \pm 0.0200$ & $316.3 \pm 0.06$ & $2.108 \pm 0.001$ & $1006.33 \pm 1.53$ \\
\hline Mean & & $4.24 \pm 0.20^{b}$ & $11.74 \pm 0.47^{a}$ & $0.207 \pm 0.04^{a}$ & $287.46 \pm 22.95^{b}$ & $2.065 \pm 0.06^{b}$ & $985.33 \pm 19.64^{c}$ \\
\hline \multirow[t]{3}{*}{ Hypotrigona sp. } & । & $3.85 \pm 0.111$ & $18.310 \pm 0.900$ & $0.317 \pm 0.0058$ & $399.1 \pm 0.35$ & $2.103 \pm 0.001$ & $724.33 \pm 0.58$ \\
\hline & $\|$ & $3.65 \pm 0.036$ & $17.053 \pm 0.489$ & $0.270 \pm 0.0200$ & $349.0 \pm 0.36$ & $1.861 \pm 0.001$ & $630.00 \pm 1.73$ \\
\hline & III & $3.75 \pm 0.042$ & $17.127 \pm 0.239$ & $0.323 \pm 0.0493$ & $362.0 \pm 0.15$ & $1.886 \pm 0.001$ & $682.67 \pm 0.58$ \\
\hline Mean & & $3.75 \pm 0.11^{a}$ & $17.50 \pm 0.80^{c}$ & $0.303 \pm 0.04^{b}$ & $370.01 \pm 22.51^{c}$ & $1.950 \pm 0.12^{b}$ & $679.00 \pm 40.95^{a}$ \\
\hline \multirow[t]{3}{*}{ Melipona sp. } & I & $3.80 \pm 0.027$ & $13.507 \pm 0.047$ & $0.217 \pm 0.0152$ & $209.0 \pm 0.31$ & $1.533 \pm 0.000$ & $762.33 \pm 2.31$ \\
\hline & $\|$ & $4.18 \pm 0.066$ & $15.203 \pm 0.186$ & $0.240 \pm 0.0100$ & $211.7 \pm 0.15$ & $2.012 \pm 0.001$ & $792.33 \pm 1.15$ \\
\hline & III & $4.65 \pm 0.053$ & $12.863 \pm 0.221$ & $0.257 \pm 0.0153$ & $221.2 \pm 0.15$ & $1.632 \pm 0.001$ & $805.33 \pm 0.58$ \\
\hline Mean & & $4.21 \pm 0.37^{b}$ & $13.86 \pm 1.06^{b}$ & $0.238 \pm 0.02^{a}$ & $214.00 \pm 5.55^{a}$ & $1.726 \pm 0.22^{a}$ & $786.67 \pm 19.14^{b}$ \\
\hline
\end{tabular}

Results were expressed as mean \pm standard deviation of duplicate experiments. Means were compared by using One way ANOVA and Games-Howell Post Hoc Multiple Comparisons. In each column, mean values with different letters (superscripts "a-c") indicate significant differences ( $p<0.05$ )

EC, electrical conductivity; TDS, total dissolved solids; Colour (absorbance at $560 \mathrm{~nm}$ ); $\mathrm{ABS}_{450}$, colour intensity. Hypotrigona sp. honey-Okotobo honey and Melipona sp. honey-Ifufu/lhuhu honey

Table 2 Biochemical properties of the honeys

\begin{tabular}{|c|c|c|c|c|c|c|c|c|c|}
\hline \multirow{2}{*}{$\begin{array}{l}\text { Honey } \\
\text { source }\end{array}$} & \multirow[t]{2}{*}{ Samples } & \multicolumn{8}{|l|}{ Parameters } \\
\hline & & $\begin{array}{l}\text { Total sugar } \\
\text { contents } \\
{[(\%) g / g]}\end{array}$ & $\begin{array}{l}\text { Reducing } \\
\text { sugar }[(\%) \\
\mathbf{g} / \mathbf{g})]\end{array}$ & $\begin{array}{l}\text { Sucrose }[(\%) \\
\mathrm{g} / \mathrm{g}]\end{array}$ & $\begin{array}{l}\mathrm{HMF}(\mathrm{Mg} / \\
\mathrm{kg})\end{array}$ & $\begin{array}{l}\text { Total protein } \\
\text { contents }(\mathrm{g} / \\
\mathrm{kg})\end{array}$ & $\begin{array}{l}\text { Total acidity } \\
\text { (meq/kg) }\end{array}$ & $\begin{array}{l}\text { Free acidity } \\
\text { (meq/kg) }\end{array}$ & $\begin{array}{l}\text { Lactone } \\
\text { acidity } \\
\text { (meq/kg) }\end{array}$ \\
\hline \multirow[t]{3}{*}{ Apis mellifera } & । & $79.61 \pm 0.03$ & $77.26 \pm 0.03$ & $2.35 \pm 0.01$ & $13.17 \pm 0.05$ & $3.05 \pm 0.05$ & $21.93 \pm 0.03$ & $18.31 \pm 0.11$ & $3.62 \pm 0.09$ \\
\hline & $\|$ & $70.17 \pm 0.21$ & $67.75 \pm 0.19$ & $2.42 \pm 0.02$ & $11.97 \pm 0.05$ & $3.11 \pm 0.02$ & $22.07 \pm 0.10$ & $19.46 \pm 0.43$ & $2.94 \pm 0.08$ \\
\hline & III & $68.32 \pm 0.01$ & $66.00 \pm 0.02$ & $2.32 \pm 0.01$ & $16.12 \pm 0.12$ & $3.94 \pm 0.01$ & $20.96 \pm 0.32$ & $18.24 \pm 0.25$ & $2.71 \pm 0.07$ \\
\hline Mean & & $72.70 \pm 7.5^{b}$ & $70.34 \pm 7.49^{b}$ & $2.36 \pm 0.05^{b}$ & $13.75 \pm 1.85^{b}$ & $13.75 \pm 1.85^{b}$ & $21.65 \pm 0.55^{b}$ & $18.67 \pm 0.64^{b}$ & $3.09 \pm 0.41^{b}$ \\
\hline \multirow{3}{*}{$\begin{array}{l}\text { Hypotrigona } \\
\text { sp. }\end{array}$} & । & $62.72 \pm 0.01$ & $60.72 \pm 0.02$ & $1.99 \pm 0.02$ & $16.39 \pm 0.08$ & $6.58 \pm 0.03$ & $35.70 \pm 0.22$ & $30.85 \pm 0.29$ & $4.85 \pm 0.10$ \\
\hline & $\|$ & $66.32 \pm 0.01$ & $64.64 \pm 0.02$ & $1.67 \pm 0.02$ & $16.29 \pm 0.04$ & $4.99 \pm 0.04$ & $35.08 \pm 0.30$ & $30.89 \pm 0.22$ & $4.19 \pm 0.19$ \\
\hline & III & $57.94 \pm 0.03$ & $56.12 \pm 0.04$ & $1.82 \pm 0.02$ & $17.07 \pm 0.05$ & $5.67 \pm 0.02$ & $35.93 \pm 0.07$ & $30.34 \pm 0.03$ & $5.59 \pm 0.06$ \\
\hline Mean & & $62.32 \pm 5.25^{a}$ & $60.49 \pm 5.21^{a}$ & $1.83 \pm 0.14^{a}$ & $16.58 \pm 0.37 c$ & $16.58 \pm 0.37$ & $35.57 \pm 0.42^{c}$ & $30.69 \pm 0.32^{a}$ & $4.88 \pm 0.61^{c}$ \\
\hline \multirow[t]{3}{*}{ Melipona sp. } & । & $80.53 \pm 1.59$ & $75.73 \pm 2.25$ & $4.79 \pm 0.95$ & $5.50 \pm 0.03$ & $2.97 \pm 0.04$ & $12.43 \pm 0.10$ & $10.63 \pm 0.16$ & $1.80 \pm 0.07$ \\
\hline & $\|$ & $79.55 \pm 0.44$ & $73.72 \pm 0.46$ & $5.82 \pm 0.02$ & $5.65 \pm 0.04$ & $3.94 \pm 0.01$ & $12.95 \pm 0.07$ & $11.62 \pm 0.12$ & $1.32 \pm 0.07$ \\
\hline & III & $82.04 \pm 0.19$ & $77.47 \pm 0.20$ & $4.57 \pm 0.02$ & $5.35 \pm 0.12$ & $3.78 \pm 0.01$ & $12.40 \pm 0.03$ & $11.43 \pm 0.05$ & $1.04 \pm 0.07$ \\
\hline Mean & & $80.71 \pm 1.37^{c}$ & $75.64 \pm 1.99^{c}$ & $5.06 \pm 0.75^{c}$ & $5.50 \pm 1.15^{a}$ & $5.50 \pm 1.15^{a}$ & $12.59 \pm 0.27^{a}$ & $11.23 \pm 0.4 x^{c}$ & $1.39 \pm 0.34^{a}$ \\
\hline
\end{tabular}

Results were expressed as mean \pm standard deviation of duplicate experiments. Means were compared using One way ANOVA and Games-Howell Post Hoc Multiple Comparisons. In each column, mean values with different letters (superscripts "a- $c$ ") indicate significant differences $(p<0.05)$

HMF, hydroxymethyl furfural. Hypotrigona sp. honey_Okotobo honey and Melipona sp. honey—Ifufu/lhuhu honey

content $\left(\mathrm{F}_{(2,24)}=13.767\right), \operatorname{AEAC}\left(\mathrm{F}_{(2,15)}=13.38\right)$ and FRAP $\left(\mathrm{F}_{(2,15)}=643.33(p<0.05)\right.$ of the investigated honeys (Table 3). The honey samples from Hypotrigona sp. had significantly the highest mean value of total phenolic acid content $\left(527.41 \pm 3.60 \mathrm{mg}{ }_{\mathrm{GAE}} / \mathrm{kg}\right)$, proline content $(430.17 \pm 51.45 \mathrm{mg} / \mathrm{kg})$, ascorbic acid content $(161.69 \pm 6.70 \mathrm{mg} / \mathrm{kg}), \operatorname{AEAC}(342.33 \pm 0.78 \mathrm{mg} / \mathrm{kg})$ and FRAP $(666.88 \pm 1.73) \mu \mathrm{M} \mathrm{Fe}(\mathrm{II}) / 100 \mathrm{~g}$. Apart from having the highest flavonoid contents, Melipona sp. honey had more of these parameters than Apis mellifera honey (Table 3).

\section{Correlation among some physicochemical and antioxidant parameters}

The correlation matrixes showed significant correlations between some of the physicochemical and antioxidant 
Table 3 Antioxidant properties of the honeys

\begin{tabular}{|c|c|c|c|c|c|c|c|}
\hline \multirow[t]{2}{*}{ Honey source } & \multirow[t]{2}{*}{ Samples } & \multicolumn{6}{|l|}{ Parameters } \\
\hline & & $\begin{array}{l}\text { Total phenol con- } \\
\text { tents }\left(\mathrm{mg}_{\mathrm{GAE}} / \mathrm{kg}\right)\end{array}$ & $\begin{array}{l}\text { Flavonoids con- } \\
\text { tents }\left(\mathrm{mg}_{\mathrm{CEQ}} / \mathrm{kg}\right)\end{array}$ & $\begin{array}{l}\text { Proline contents } \\
(\mathrm{mg} / \mathrm{kg})\end{array}$ & $\begin{array}{l}\text { Ascorbic acid } \\
\text { contents (mg/kg) }\end{array}$ & $\begin{array}{l}\text { AEAC contents } \\
(\mathrm{mg} / \mathrm{kg})\end{array}$ & $\begin{array}{l}\operatorname{FRAP}(\mu \mathrm{M} \\
\mathrm{Fe}(\mathrm{II}) / 100 \mathrm{~g}\end{array}$ \\
\hline \multirow[t]{3}{*}{ Apis mellifera } & । & $409.73 \pm 1.95$ & $57.00 \pm 0.16$ & $338.89 \pm 0.13$ & $157.44 \pm 0.49$ & $304.51 \pm 0.16$ & $525.68 \pm 0.83$ \\
\hline & $\|$ & $432.07 \pm 0.10$ & $62.35 \pm 1.09$ & $339.21 \pm 0.01$ & $161.96 \pm 0.05$ & $299.22 \pm 8.44$ & $508.45 \pm 17.51$ \\
\hline & III & $475.68 \pm 0.41$ & $65.82 \pm 0.29$ & $481.27 \pm 0.03$ & $149.48 \pm 0.28$ & $290.67 \pm 0.58$ & $500.06 \pm 0.05$ \\
\hline Mean & & $439.16 \pm 29.06^{b}$ & $61.72 \pm 3.89^{b}$ & $386.46 \pm 71.11^{b}$ & $156.29 \pm 5.48^{b}$ & $298.13 \pm 7.38^{a}$ & $511.40 \pm 14.31^{b}$ \\
\hline \multirow[t]{3}{*}{ Hypotrigona sp. } & I & $531.10 \pm 0.05$ & $52.52 \pm 0.03$ & $498.52 \pm 0.04$ & $169.27 \pm 0.04$ & $343.04 \pm 0.89$ & $668.53 \pm 0.23$ \\
\hline & $\|$ & $522.91 \pm 0.10$ & $28.19 \pm 0.03$ & $401.26 \pm 0.26$ & $153.80 \pm 0.07$ & $342.34 \pm 0.29$ & $667.24 \pm 1.22$ \\
\hline & III & $375.82 \pm 0.25$ & $43.41 \pm 0.22$ & $390.73 \pm 0.25$ & $162.01 \pm 0.23$ & $341.62 \pm 0.92$ & $664.87 \pm 0.22$ \\
\hline Mean & & $527.41 \pm 3.60^{c}$ & $41.37 \pm 10.65^{a}$ & $430.17 \pm 51.45^{b}$ & $161.69 \pm 6.70^{c}$ & $342.33 \pm 0.78^{b}$ & $666.88 \pm 1.73^{c}$ \\
\hline \multirow[t]{3}{*}{ Melipona sp. } & I & $386.09 \pm 0.11$ & $82.78 \pm 0.39$ & $281.28 \pm 0.06$ & $149.69 \pm 0.27$ & $293.44 \pm 0.49$ & $439.15 \pm 0.34$ \\
\hline & $\|$ & $354.03 \pm 0.08$ & $83.79 \pm 0.06$ & $276.11 \pm 0.03$ & $151.62 \pm 0.34$ & $297.49 \pm 3.77$ & $424.28 \pm 12.69$ \\
\hline & III & $375.82 \pm 0.25$ & $92.60 \pm 0.10$ & $338.84 \pm 0.07$ & $144.31 \pm 0.08$ & $299.77 \pm 1.35$ & $417.36 \pm 0.52$ \\
\hline Mean & & $371.98 \pm 14.18^{a}$ & $86.39 \pm 4.69^{c}$ & $298.74 \pm 3016^{a}$ & $148.54 \pm 3.29^{a}$ & $296.99 \pm 3.43^{a}$ & $426.93 \pm 11.55^{a}$ \\
\hline
\end{tabular}

Results were expressed as mean \pm standard deviation of duplicate experiments. Means were compared by using One way ANOVA and Games-Howell Post Hoc

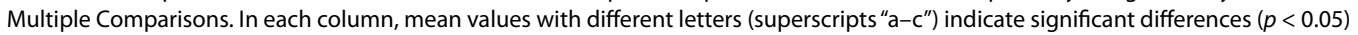

GAE, gallic acid equivalent; CEQ, catechin equivalent; FRAP, ferric reducing/antioxidant power assay; AEAC, antioxidant equivalent-ascorbic acid assay. Hypotrigona sp. honey-Okotobo honey and Melipona sp. honey-Ifufu/lhuhu honey

parameters. In A. mellifera honey samples, a strong correlation was found between colour intensity and some parameters (Additional file 1: Table S1). Also, correlation matrixes of Hypotrigona sp. honey samples showed strong correlations between $\mathrm{ABS}_{450}$ and phenolics flavonoid, protein, ascorbic acid and AEAC. The proline content had positive correlations with total phenol content, AEAC, FRAP and flavonoid content (Additional file 1: Table S2). Several strong positive correlations were established between $\mathrm{ABS}_{450}$ of Melipona sp. and protein and AEAC. The flavonoid contents had correlation with proline, AAC, AEAC and FRAP (Additional file 1: Table S3).

\section{Discussion}

All honey varieties analysed were acidic. The observed $\mathrm{pH}$ values in this study are comparatively similar to previous reports for Nigerian stinging bee honey (3.32 and 4.90) $[6,9]$ and higher than stingless bee honeys (1.403.97) [10]. None of the investigated samples exceeded the allowed limit of international standards $(\mathrm{pH}$ of 3.42-6.10) [25]. The moisture content of the honey samples are within the recommended international standard limit (not more than 20\%) $[25,26]$. The moisture content of the tested honeys may be related to the harvest season and the level of maturity in the hive [11]. While similar findings have been reported by Omoya et al. [7] and Eleazu et al. [9], and a higher moisture content values (25.43-26.51\%) has been reported for Nigeria stingless bee honey [10]. Hypotrigona sp. honey showed the highest mean $\mathrm{EC}$ value and the highest mean content of TDS, which indicates that it is rich in both organic and inorganic substances [12]. The EC values of the investigated honey samples are within the allowed limit of international standards (not more than $0.8 \mathrm{mSs} / \mathrm{cm}$ ) [25]. This is the first report on $\mathrm{ABS}_{450}$ of Nigeria honeys and similarly, the $\mathrm{ABS}_{450}$ values for Slovenian, Algerian and Indian honeys were reported to be 70-495 mAU [14], 724-1188 mAU [27], and 524-1678 mAU [16]), respectively. Comparatively, a smaller strong correlation was found between the colour intensity of Malaysian [28] and Algerian [27] honey samples and the other antioxidant parameters, like flavonoid.

In this study, Hypotrigona sp. and Melipona sp. honeys had the highest and lowest mean total sugar content value, respectively. The sugars contents values are within the limits (Reducing sugar-not less than $60 \%$ (g/100 g) and sucrose-not more than $5 \%[\mathrm{~g} / 100 \mathrm{~g})]$ set by the Codex Alimentarius [25] and European Commission [26]. Hypotrigona sp. had the highest mean HMF value and our results were within the recommended standard set by Codex Alimentarius [25] and EU [26] (maximum of $40 \mathrm{mg} / \mathrm{kg}$ ). These findings are similar to other published levels for HMF on Nigerian honeys (5.0-17.22 mg/ $\mathrm{kg}$ ) [8], Algerian honeys $(15.23-24.21 \mathrm{mg} / \mathrm{kg})$ [27] and Pakistan honeys (27.69-36.08 mg/kg) [29]. The low HMF concentrations confirmed that these samples are of good quality. The free acidity values of the analysed honey samples are within the international standard (not more than $50 \mathrm{meq} / \mathrm{kg}$ ) [25].

The total polyphenol content of analysed A. mellifera honey samples are lower than previous report on Nigerian honey samples (846.00-1087.00 $\mathrm{mg}_{\mathrm{GAE}} / \mathrm{kg}$ ) [9] and 
comparatively similar to Algerian (411.10-498.16 mg GAE $/ \mathrm{kg}$ ) [27] and Malaysian (144.51-580.03 mg GAE $/ \mathrm{kg}$ ) [28] honeys. There was no strong positive correlation between total polyphenol content and AEAC or FRAP, although, a weak positive correlations have been reported for Algerian honey [27]. Melipona sp. honey showed the highest flavonoid contents values, followed by $\mathrm{A}$. mellifera honey, similar to Algerian honey (27.07-71.78 mg $\mathrm{CEQ} / \mathrm{kg}$ ) [27] and Turkish honeys (28.17-87.01 mg $\mathrm{CEQ}^{\prime}$ $\mathrm{kg})$ [3]. Malaysian honey has been reported to have a correlation (0.782) between flavonoid and FRAP [28], unlike observed in this study. In this study, the stingless bee honeys showed higher ascorbic acid content values than previously reported for Nigerian stingless bee honey $(119.5-120.0 \mathrm{mg} / \mathrm{kg}$ ) [10] and Portugal (140-145 mg/kg) [22]. The AEAC content values observed in this study are within the range of values reported for honeys from India (151-295 mg of AEAC/kg) [16] and Algeria (236.80$315.90 \mathrm{mg}$ of AEAC/ $\mathrm{kg}$ ) [27]. All honey varieties investigated showed high FRAP values, confirming its high antioxidant properties and are similar to that reported for Malaysian honeys (209.28-653.75 $\mu \mathrm{M} \mathrm{Fe}(\mathrm{II}) / 100 \mathrm{~g})$ [28] and Italian honey (216.57-695.64 $\mu \mathrm{M} \mathrm{Fe}(\mathrm{II}) / 100 \mathrm{~g})$ [30], but higher than Algerian honeys (287.45-403.54 $\mu \mathrm{M}$ $\mathrm{Fe}(\mathrm{II}) / 100 \mathrm{~g})$ [27].

\section{Conclusion}

Our results clearly indicate that Hypotrigona sp. honey possesses the best antioxidant property when compared with honeys from A. mellifera and Melipona sp. Hypotrigona sp. (Okotobo) and Melipona sp. (Ifufu) honeys are not widely consumed as regular bee honey but this study has shown that they contain bioactive compounds similar to those of regular bee honey.

\section{Limitations}

This study was performed using some of the standard analytical procedures and it has main limitations in terms of the number of honey samples and methods used, which may have resulted in underestimation of the parameters. A more precise equipment such as HPLC should in future be used to determine these parameters.

\section{Additional file}

Additional file 1. Interrelation among some physicochemical and antioxidant parameters of different honey types.

\section{Abbreviations}

EC: electrical conductivity; TDS: total dissolved solids; HMF: hydroxymethylfurfural; $\mathrm{ABS}_{450}$ : colour intensity; $\mathrm{AEAC}$ : antioxidant equivalent-ascorbic acid content; FRAP: ferric reducing/antioxidant power; DNSA: 3,5-dinitrosalicylic acid; CEQ: catechin equivalents; GAE: gallic acid equivalents; ANOVA: analysis of variance.

\section{Authors' contributions}

JAN and JEN: study concept and design, samples' analyses, data analysis and interpretation, manuscript writing and editing and submission; EIN and JIO: study concept and design, study supervision, data analysis and interpretation, manuscript writing and editing and submission. All authors read and approved the final manuscript.

\section{Acknowledgements}

The authors wish to thank Hezekiah Lab Consult, Nsukka, Nigeria for their technical assistance in carrying out some aspect of this work. The honey samples were collected with the permission of the keepers at Enugu Ezike, Enugu State, Nigeria.

\section{Competing interests \\ The authors declare that they have no competing of interests.}

\section{Availability of data and materials}

Data are all contained within the paper. The datasets from the analyses are available from the corresponding author on reasonable request.

\section{Consent for publication \\ Not applicable.}

Ethics approval and consent to participate Not applicable.

Funding

The authors declared that there was no funding.

\section{Publisher's Note}

Springer Nature remains neutral with regard to jurisdictional claims in published maps and institutional affiliations.

Received: 2 September 2017 Accepted: 27 October 2017

Published online: 06 November 2017

\section{References}

1. Bogdanov S. Book of honey: honey composition. Bee product science. 2009; 1-9. http://fantasticflavour.com/yahoo_site_admin/assets/docs/ CompositionHoney.20105942.pdf. Accessed 13 Sept 2015.

2. IHC. Harmonized methods of the International Honey Commission. Swiss Bee Research Centre. FAM. Swizerland: Liebefeld; 2002.

3. Souza B, Roubik D, Barth O, Heard T, lquez EE, Carvalho C, Villas-Bôas J, Marchini F, Locatelli J, Persano-Oddo L, Almeida-Muradian L, Bogdanov S, Vit P. Composition of stingless bee honey: setting quality standards. Interciencia. 2006;31(12):867-75.

4. Singh MP, Chourasia HR, Agarwal M, Malhotra A, Sharma M, Sharma D, Khan S. Honey as complementary medicine - a review. Int J Pharma Bio Sci. 2012;3(2):12-31.

5. Agbagwa OE, Otokunefor TV, Frank-Peterside N. Quality assessment of Nigeria honey and manuka honey. J Microbiol Biotechnol Res. 2011;1(3):20-31.

6. Omafuvbe BO, Akanbi OO. Microbiological and physico-chemical properties of some commercial Nigerian honey. Afr J Microbiol Res. 2009;3(12):891-6.

7. Omoya FO, Ijabadeniyi OA, Ogonnoh OB. Physicochemical properties of honey samples from Ondo state, Nigeria, and their bioactivity against spoilage and pathogenic organisms. J Food Agric Environ. 2014;12(34):104-7.

8. Buba F, Gidado A, Shugaba A. Physicochemical and microbiological properties of honey from North East Nigeria. Biochem Anal Biochem. 2013;2(142):61-7. https://doi.org/10.4172/2161-1009.1000142.

9. Eleazu CO, Iroaganachi MA, Eleazu KC, Okoronkwo JO. Determination of the physico-chemical composition, microbial quality and free radical scavenging activities of some commercially sold honey samples in Aba, Nigeria: the effect of varying colours. Int J Biomed Res. 2013;04(01):32-41. 
10. Onyenso AL, Akachuku CO. Physico-chemical properties of honeys produced by two stingless bee species - Trigonacarbonaria and Melipona Beecheii in South-Eastern Nigeria. J Agric Forest Soc Sci. 2011;9(1):19-26.

11. AOAC. Official methods of analysis. 15th ed. Association of official analytical chemist chemists (AOAC). Washington, DC; 1990.

12. Bogdanov S, Martin P, Lüllmann C. Harmonised methods of the European honey commission. Apidologie. 1997;28:1-59.

13. White JW. Instrumental colour classification of honey: collaborative study. J Assoc Off Anal Chem. 1984;67:1129-31.

14. Beretta G, Granata P, Ferrero M, Orioli M, Facino RM. Standardization of antioxidant properties of honey by a combination of spectrophotometric/fluorimetric assays and chemometrics. Anal ChimicaActa. 2005;533(2):185-91.

15. AOAC. Sugars and sugar products: official methods of analysis, 17 th ed. Horowitz W, editor. Gaithersburg: AOAC International; 2000.

16. Saxena S, Gautam S, Sharma A. Physical, biochemical and antioxidant properties of some Indian honeys. Food Chem. 2010;118:391-7.

17. Winkler C. BeitragZurNachweis und ZurBestimmung Von Kunsthoning. ZeitschrLebensmUntersForsch. 1955;102(161-167):25.

18. Auerbach F, Borries G. Auerbach and Borries equation. Z NahrGenssm. 1924;22:353-8.

19. Lowry OH, Rosebrough NJ, Farr AL, Randall RJ. Protein measurement with the Folin phenol reagent. J Biol Chem. 1951;193:265.

20. Singleton VL, Orthofer R, Lamuela-Raventos RM. Analysis of total phenols and other oxidation substrates and antioxidants by means of FolinCiocalteu reagent. Methods Enzymol. 1999;299:152-78.

21. Zhishen J, Mengcheng T, Jianming W. The determination of flavonoid contents in mulberry and their scavenging effects on superoxide radicals. Food Chem. 1999;64:555-9.

22. Ferreira IC, Airers E, Barreira JCM, Estevinho LM. Antioxidant activity of Portuguese honey samples: different contributions of the entire honey and phenolic extract. Food Chem. 2009;144:1438-43.
23. Meda A, Lamien CE, Romito M, Millogo J, Nacoulma OG. Determination of the total phenolic, flavonoid and proline contents in Burkina Fasan honey, as well as their radical scavenging activiity. Food Chem. 2005;91:571-7.

24. Bertoncelj J, Doberšek U, Jamnik M, Golob T. Evaluation of the phenolic content, antioxidant activity and colour of Slovenian honey. Food Chem. 2007;105:822-8.

25. Codex Alimentarius. Codex standard 12, Revised codex standard for honey, standards and standard methods, vol. 11;2002. http://www. codexalimentarius.net. Accessed 14 June 2015.

26. EU Council: European Union Council directive 2001/110/EC of 20 December 2001 relating to honey. Off J Eur Communities. 2002;L10:47-52.

27. Khalil IM, Moniruzzaman M, Boukraâ L, Benhanifia M, Islam MA, Islam MN, Sulaiman SA, Gan SH. Physicochemical and antioxidant properties of Algerian honey. Molecules. 2012;17(9):11199-215. https://doi. org/10.3390/molecules170911199.

28. Moniruzzaman M, Sulaiman SA, Khalil MI, Gan SH. Evaluation of physicochemical and antioxidant properties of sourwood and other Malaysian honeys: a comparison with manuka honey. Chem Central J. 2013;7(138):1-12.

29. Fahim H, Dasti Jl, Ali I, Ahmed S, Nadeem M. Physico-chemical analysis and antimicrobial potential of Apis dorsata, Apis mellifera and Ziziphus jujube honey samples from Pakistan. Asian Pac J Trop Biomed. 2014;4(8):633-41.

30. Perna A, Simonetti A, Intaglietta I, Gambacorta E. Antioxidant properties, polyphenol content and colorimetric characteristics of different floral origin honeys from different areas of Southern Italy. J Life Sci. 2013;7(4):428-36.

\section{Submit your next manuscript to BioMed Central and we will help you at every step:}

- We accept pre-submission inquiries

- Our selector tool helps you to find the most relevant journal

- We provide round the clock customer support

- Convenient online submission

- Thorough peer review

- Inclusion in PubMed and all major indexing services

- Maximum visibility for your research

Submit your manuscript at www.biomedcentral.com/submit
O Biomed Central 